\title{
Serosurvey of vector-borne diseases in the Mexican wolf (Canis lupus baileyi) in captivity
}

\author{
Estudio serológico de enfermedades transmitidas por vectores en el lobo mexicano \\ (Canis lupus baileyi) en cautiverio
}

\author{
F Morales-Soto ${ }^{\mathrm{a}}$, C García-De la Peña ${ }^{\mathrm{b} *}$, RI Rodríguez-Vivas ${ }^{\mathrm{c}}$, R Rodríguez-Martínez $^{\mathrm{a}}$ \\ aUniversidad Autónoma Agraria Antonio Narro, Unidad Laguna, Coahuila, México. \\ bLaboratorio de Medicina de la Conservación, Facultad de Ciencias Biológicas, Universidad Juárez del estado de Durango, \\ Durango, México. \\ ${ }^{c}$ Facultad de Medicina Veterinaria y Zootecnia, Campus de Ciencias Biológicas y Agropecuarias, \\ Universidad Autónoma de Yucatán, Yucatán, México.
}

\begin{abstract}
RESUMEN
Las enfermedades transmitidas por vectores afectan el estado de salud de los caninos en todo el mundo. Se examinaron muestras de suero de seis lobos mexicanos cautivos (Canis lupus baileyi) en la Reserva de la Biosfera La Michilía, Durango, México, para detectar anticuerpos contra Anaplasma phagocytophilum, Ehrlichia canis y Borrelia burgdorferi, así como el antígeno contra Dirofilaria spp. Las muestras de sangre se colectaron de la vena cefálica y se centrifugaron para obtener los sueros, que posteriormente fueron analizados utilizando pruebas de ELISA IgG disponibles en el mercado. Uno de los seis individuos resultó positivo para anticuerpos contra A. phagocytophilum. Este lobo positivo (macho, 13 años) nació en la Reserva, donde vivió toda su vida, pero nunca mostró signos de enfermedad. La conservación del lobo mexicano es una prioridad internacional y ante la evidencia de anticuerpos contra A. phagocytophilum registrados en un individuo de esta especie en la Reserva de la Biosfera de La Michilía se recomiendan estudios posteriores acerca de detección molecular de esta bacteria, el papel de los posibles vectores y la inmunidad de este lobo al patógeno.
\end{abstract}

Palabras clave: lobo, México, ELISA, Anaplasma.

\section{SUMMARY}

Vector-borne diseases affect the health status of canines worldwide. We examined serum samples from six captive Mexican wolves (Canis lupus baileyi) at the Reserva de la Biosfera La Michilía, Durango, México for antibodies against Anaplasma phagocytophilum, Ehrlichia canis, Borrelia burgdorferi, and the antigen against Dirofilaria spp. Blood samples were collected from the cephalic vein and centrifuged to obtain sera, to be assayed using commercially available IgG ELISA tests. One of the six individuals tested positive for antibodies to A. phagocytophilum. The positive-tested wolf (male, 13 year-old) was born at the Reserve and had lived there all his life, but had never showed signs of illness. Conservation of the Mexican wolf is an international priority and due to the evidence of antibodies against A. phagocytophilum found in this animal species at the Reserva de la Biosfera de la Michilía, further studies on molecular detection of this bacteria, the role of potential vectors, and wolf immunity to this pathogen are recommended.

Key words: wolf, México, ELISA, Anaplasma.

\section{INTRODUCTION}

The Mexican wolf is the smallest subspecies of gray wolf, originally found in semi-arid regions within temperate pine-oak forests of southwestern North America. In 1976 the Binational Mexican Wolf Recovery Program was initiated with the goal to produce genetically healthy captive groups of wolves which could then be reintroduced as wild populations within their historic range. The U.S.A and Mexico decided to remove the last wild wolves from the states of Durango and Chihuahua to begin an intensive captive breeding program (Servín-Martínez 2007). One of the objectives of the Reserva de la Biosfera La Michilía in Durango, Mexico, is to conserve animal diversity in representative natural ecosystems (Halffter

Accepted: 03.08.2015.

* Av. Universidad s/n Fraccionamiento Filadelfia, Gómez Palacio, Durango, México. C.P. 35010; cristina.g.delapena@gmail.com
1984), and has participated in the Mexican wolf (Canis lupus baileyi) recovery program by keeping individuals in captivity within a pine-oak forest habitat. Today, this wolf is considered extinct in the wild in Mexico (SEMARNAT 2010). As with other species of canids, Mexican wolves are susceptible to vector-borne diseases, which are increasingly prevalent worldwide as tick and mosquitoes distributions expand through climate change and wildlife migration. In order to evaluate the occurrence of such diseases in the captive wolves at Michilía we evaluated their antibody reactions to the pathogens Anaplasma phagocytophilum, Ehrlichia canis, and Borrelia burgdorferi, and the antigen against Dirofilaria spp.

\section{MATERIAL AND METHODS}

The Reserva de la Biosfera La Michilía is located in the southeast of Durango, Mexico, municipalities of 


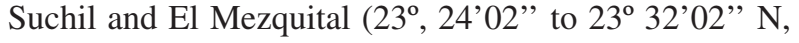
and $104^{\circ} 08^{\prime} 45^{\prime \prime}$ to $104^{\circ} 19^{\prime} 52^{\prime \prime}$ W). In September 2013 Mexican wolves at the Reserve were captured using nets, using care to ensure the safety of the animals as well as the veterinarians and biologists handling wolves (protocols for large canines suggested by the Association of Zoos and Aquariums, AZA Canid Tag 2012). Each animal was given a physical examination, and any signs of diseases were recorded. For each animal blood samples were collected from the cephalic vein using $3 \mathrm{ml}$ Vacutainer ${ }^{\circledR}$ tubes. Samples were transported at $4{ }^{\circ} \mathrm{C}$ to the field laboratory. Blood was centrifuged at $1.500 \mathrm{rpm}$ for 10 minutes to obtain serum. We assayed serum samples for antibodies against A. phagocytophilum, Ehrlichia canis, and Borrelia burgdorferi, and the antigen against Dirofilaria spp. using SNAP ${ }^{\circ} 4 \mathrm{Dx} \circledast$ ELISA IgG tests commercially available from IDEXX®. This test uses purified antigens that provide greater sensitivity and specificity when employing whole cell tests (IFA and Western blot); this is because peptide-based technology only evaluates the presence of highly specific antibodies against agents, which eliminates false positives. Using whole cells to detect all antibodies produced against these microorganisms can give false positives (IDEXX®).

\section{RESULTS AND DISCUSSION}

Six adult Mexican wolves were captured (3 females and 3 males). Based on physical inspections, all wolves were considered healthy; however one Mexican wolf, a 13-yr-old male, was found to be seropositive to antibodies for A. phagocytophilum. The other five Mexican wolves were seronegative to A. phagocytophilum, and all six were negative to E. canis and B. burgdorferi antibodies, as well as to the Dirofilaria antigen. The present study is the first to report antibodies against A. phagocytophilum in a Mexican wolf in Mexico.

The A. phagocytophilum bacteria causes granulocytic anaplasmosis, a disease that can affect humans as well as domestic and wild animals (De la Fuente et al 2005, Woldehiwet 2010). The bacterium infects and survives within neutrophils by disabling key neutrophil functions, including neutrophil motility, phagocytosis, the oxidative burst mechanism, and neutrophil-endothelial cell interactions, as well as interfering with neutrophil apoptosis; clinical signs in dogs, and presumably wolves, include fever, lethargy, lack of appetite, lameness, coughing, polydipsia, intermittent vomiting, and hemorrhages (Carrade et al 2009).

There is a report of acute granulocytic anaplasmosis in a captive timber wolf kept in an outdoor enclosure in Austria showing anorexia, depression, and fever. According to Leschnik et al (2012) granulocytic anaplasmosis is known to be a common infectious disease in dogs (although not all animals develop clinical signs), but in wildlife, symptomatic anaplasmosis might be a rare disease.
In Mexico, A. phagocytophilum antibodies in dogs have been reported. Recently, Salinas-Meléndez et al (2014) and Silva et al (2014) reported 3.0\% and 7.4\% of dogs from Monterrey and Oaxaca, Mexico, had antiA. phagocytophilum antibodies. Recently, Leschnik et al (2012) reported for the first time acute granulocytic anaplasmosis in a captive timber wolf (Canis lupus occidentalis) in Austria. Clinical symptoms and temporary changes in blood parameters in this wolf were similar to granulocytic anaplasmosis seen in dogs. This was the first report on granulocytic anaplasmosis in a wolf, indicating that $A$. phagocytophilum might cause clinical disease in this species.

Anaplasma phagocytophilum is transmitted by hard ticks of the Ixodes persulcatus-complex. I. scapularis is present in the north, central and south regions of Mexico, including the states of Durango and Coahuila (Guzmán-Cornejo and Robbins 2010). It has been reported on Bovidae, Canidae, Cervidae and Leporidae (Guzmán-Cornejo et al 2007, Romero-Castañón et al 2008, Gordillo-Pérez et al 2009). For Michilía there are I. scapularis records on coyotes (Canis latrans), grey foxes (Urocyon cinereoargenteus), white-tailed deer (Odocoileus virginianus), and eastern cottontails (Silvilagus floridanus) (Sosa-Fernández 1998), as well as on domestic dogs. Due to I. scapularis' range of host preferences and the presence of other susceptible species in Durango, the potential is there to transmit $A$. phagocytophilum to the Mexican wolf in the Reserva de la Biosfera La Michilía. According to the wolves' keeper at Michilía, the wolf that was positive to antibodies for $A$. phagocytophilum was born at the Reserve and lived there all his life, but never showed signs of illness. It is possible that he was previously exposed to tick bite and then developed immune defense mechanisms. Because conservation of the Mexican wolf is an international priority and the evidence of antibodies against $A$. phagocytophilum found in this animal species at the Reserva de la Biosfera de la Michilía, further studies on molecular detection of this bacteria, the role of potential vectors (i.e. I. scapularis), and wolf immunity to this pathogen are recommended.

\section{ACKNOWLEDGEMENTS}

We thank Instituto de Ecología A.C. for allowing access to the wolves (Permit 01-2013), R. Pineda (CONANP-Michilía), C. Quezada-Rivera, A. González-Durán, and N. Salas-Muro for their support in the field work, and C.W. Barrows for the English review. This research was carried out under Mexican permit SEMARNAT, DGVS 02416/13.

\section{REFERENCES}

AZA Canid TAG. 2012. Large Canid (Canidae) Care Manual. Association of Zoos and Aquariums, Silver Spring, Maryland, USA.

Carrade DD, JE Foley, DL Borjesson, JE Sykes. 2009. Canine granulocytic anaplasmosis: a review. J Vet Intern Med 23, 1129-1141.

De La Fuente J, V Naranjo, F Ruiz-Fons, U Höfle, IG Fernández De Mera, D Villanúa, C Almazán, A Torina, S Caracappa, KM Kocan, C Gortázar. 2005. Potential vertebrate reservoir hosts and invertebrate 
vectors of Anaplasma marginale and A. phagocytophilum in central Spain. Vector Borne Zoonotic Dis 5, 390-401.

Gordillo-Pérez G, M Vargas, F Solórzano-Santos, A Rivera, OJ Polaco, L Alvarado, O Muñoz, J Torres. 2009. Demonstration of Borrelia burgdorferi sensu stricto infection in ticks from the northeast of Mexico. Clin Microbiol Infec 15, 496-498.

Guzmán-Cornejo C, RG Robbins, TM Pérez. 2007. The Ixodes (Acari: Ixodidae) of Mexico: Parasite-host and host parasite checklists. Zootaxa 1553,47-58.

Guzmán-Cornejo C, RG Robbins. 2010. The genus Ixodes (Acari: Ixodidae) in Mexico: adult identification keys, diagnoses, hosts, and distribution. Rev Mex Biodivers 81, 289-298.

Halffter G. 1984. Las reservas de la biósfera: conservación de la naturaleza para el hombre. Acta Zool Mex n.s. 5, 1-50.

Leschnik M, G Kirtz, Z Virányi, Wille-Piazzai, G Duscher. 2012. Acute granulocytic anaplasmosis in a captive timber wolf (Canis lupus occidentalis). J Zoo Wildl Med 43, 645-648.

Romero-Castañón S, BG Ferguson, D Güiris, D González, S López, A Paredes, M Weber. 2008. Comparative parasitology of wild and domestic ungulates in the Selva Lacandona, Chiapas, Mexico. Comp Parasitol 75, 115-126.

Salinas-Meléndez JA, R Villavicencio-Pedraza, BV Tamez-Hernández, JJ Hernández-Escareño, R Ávalos-Ramírez, JJ Zarate-Ramos,
FJ Picón-Rubio, VM Riojas-Valdés. 2014. Prevalence of antiAnaplasma phagocytophilum antibodies among dogs from Monterrey, Mexico. Afr J Microbiol Res 8, 825-829.

SEMARNAT. 2010. NOM-059-SEMARNAT-2010, Protección ambientalEspecies nativas de México de flora y fauna silvestres-Categorías de riesgo y especificaciones para su inclusión, exclusión o cambioLista de especies en riesgo. Diario Oficial. Jueves 30 de diciembre de 2010, México, D.F.

Servín-Martínez JI. 2007. Distribución histórica, prospección actual y áreas potenciales para reintroducir lobo mexicano (Canis lupus baileyi) en Durango, sur de la Sierra Madre Occidental, México. Universidad Juárez del Estado de Durango. Informe final SNIBCONABIO proyecto No. BE029. México D. F.

Silva AB, S Pina-Canseco, MP Gabriel-De la Torre, A Mayoral-Silva, MA Mayoral, L Pérez-Campos-Mayoral, J López-Martínez, E PérezCampos. 2014. Infección humana asintomática por contacto con perros. Un caso de ehrlichiosis humana. G Med Mex 150, 171-174.

Sosa-Fernández V. 1998. Inventario de los mamíferos de las reservas de la biosfera Mapimí, La Michilía, El Cielo y Calakmul. Instituto de Ecología AC. Informe final SNIB-CONABIO proyecto No. P027. México, D.F.

Woldehiwet Z. 2010. The natural history of Anaplasma phagocytophilum. Vet Parasitol 167, 108-122. 
